\title{
WISATA KAMPUNG NELAYAN DI MUARA ANGKE
}

\author{
Yourdy Yonathan Stefanus ${ }^{1)}$, Agustinus Sutanto ${ }^{2)}$ \\ 1) Program Studi S1 Arsitektur, Fakultas Teknik, Universitas Tarumanagara, jordy.yonathan@gmail.com \\ 2) Program Studi S1 Arsitektur, Fakultas Teknik, Universitas Tarumanagara, afirawiniera@gmail.com
}

\begin{abstract}
Abstrak
Indonesia mempunyai keragaman sumber daya alam dan budaya yang sangat melimpah. Kekayaan sumber daya alam dan budaya tersebut hingga saat ini berperan penting sebagai faktor penentu perekonomian nasional. Akan tetapi, masyarakat Indonesia masih belum mengenal dan memahami peran dari keragaman sumber daya alam dan budaya yang ada. Kondisi ini cenderung menyebabkan penurunan kualitas dari nilai-nilai wisata dan nilai-nilai budaya tradisional suatu kawasan. Pesisir Muara Angke, Jakarta Utara, pada awal perkembangannya merupakan salah satu kawasan yang kaya akan keanekaragaman alam dan budaya tradisional. Potensi alam dan kearifan lokal tersebut dapat dimanfaatkan dan dikembangkan menjadi salah satu daerah tujuan wisata unggulan di Jakarta. Hal tersebut didukung oleh letaknya yang dekat dengan Hutan Lindung Muara Angke dan berbatasan langsung dengan perairan, yaitu Laut Jawa, Kali Asin, dan Kali Adem. Selain itu, pesisir Muara Angke yang dikenal sebagai lokasi pelelangan dan pelabuhan ikan memiliki tatanan kehidupan masyarakat lokal dengan sebagian besar penduduk bermata-pencaharian sebagai nelayan dan pengolah hasil perikanan yang mempunyai keterkaitan dengan sumber daya yang mereka miliki. Dalam destinasi wisata ini, terdapat fungsi-fungsi yang diharapkan dapat mengembalikan kejayaan Muara Angke. Fungsi restaurant, yang akan menjadi wadah yang dipenuhi oleh bumbu-bumbu asli khas wilayah Muara Angke. Fungsi Aquarium, yang akan meemberikan edukasi ke masyarakat kota Jakarta, untuk menginformasikan masyarakat tentang biota laut dan pentingnya untuk menjaga kelangsungan hidup laut. Dengan bentuk bangunan yang ikonik, diharapkan bangunan ini akan mengisi kekosongan di kawasan Muara Angke. Bentuk bangunan yang menyerupai kapal, yang diisi dengan restaurant, aquarium, tempat souvenir kawasan, menjadikan ikon dari kawasan Muara Angke.
\end{abstract}

Kata kunci: Jakarta, Muara Angke, rekreasi, wisata

\begin{abstract}
Indonesia has a vast diversity of natural and cultural resources. The wealth of natural and cultural resources has so far played an important role as a determinant of the national economy. However, Indonesian people still do not know and understand the role of the diversity of natural and cultural resources that exist. This condition tends to cause a decrease in the quality of tourism values and traditional cultural values of an area. Muara Angke Coast, North Jakarta, at the beginning of its development is one area that is rich in natural diversity and traditional culture. The potential of nature and local wisdom can be utilized and developed into one of the leading tourist destinations in Jakarta. This is supported by its proximity to the Muara Angke Protection Forest and directly adjacent to the waters, namely the Java Sea, Salty River, and Adem River. In addition, the coast of Muara Angke, which is known as the location of auction and fish port, has the order of life of the local community with the majority of the population making a living as fishermen and fisheries processors who have links with the resources they have. In this tourist destination, there are functions that are expected to restore the glory of Muara Angke. The function of the restaurant, which will be a container filled with native spices typical of the Muara Angke region. The function of the Aquarium, which will provide education to the people of Jakarta, to inform the public about marine biota and the importance of maintaining the survival of the sea. With an iconic building form, it is hoped that this building will fill the void in the Muara Angke area. The shape of the building that resembles a ship, which is filled with restaurants, aquariums, a place for regional souvenirs, makes it an icon of the Muara Angke area.
\end{abstract}

Keywords: Jakarta, Muara Angke, recreation, tourism 


\section{PENDAHULUAN}

Indonesia mempunyai keragaman sumber daya alam dan budaya yang sangat melimpah. Kekayaan sumber daya alam dan budaya tersebut hingga saat ini berperan penting sebagai faktor penentu perekonomian nasional. Akan tetapi, masyarakat Indonesia masih belum mengenal dan memahami peran dari keragaman sumber daya alam dan budaya yang ada. Kondisi ini cenderung menyebabkan penurunan kualitas dari nilai-nilai wisata dan nilai-nilai budaya tradisional suatu kawasan.

Pesisir Muara Angke, Jakarta Utara, pada awal perkembangannya merupakan salah satu kawasan yang kaya akan keanekaragaman alam dan budaya tradisional. Potensi alam dan kearifan lokal tersebut dapat dimanfaatkan dan dikembangkan menjadi salah satu daerah tujuan wisata unggulan di Jakarta. Hal tersebut didukung oleh letaknya yang dekat dengan Hutan Lindung Muara Angke dan berbatasan langsung dengan perairan, yaitu Laut Jawa, Kali Asin, dan Kali Adem. Selain itu, pesisir Muara Angke yang dikenal sebagai lokasi pelelangan dan pelabuhan ikan memiliki tatanan kehidupan masyarakat lokal dengan sebagian besar penduduk bermata-pencaharian sebagai nelayan dan pengolah hasil perikanan yang mempunyai keterkaitan dengan sumber daya yang mereka miliki.

Namun, potensi-potensi dari pesisir Muara Angke, tersebut mulai luntur karena pengembangan fisik yang kurang mendukung kawasan tersebut dan sekitarnya lebih mementingkan kepentingan manusia dalam segi ekonomi tanpa mempertimbangkan segi ekologi dan budaya yang ada di dalamnya. Hal tersebut dapat dilihat dengan adanya modernisasi yang mengakibatkan budaya masyarakat lokal tergusur dan pembangunan perumahan yang banyak mengambil ruang terbuka. Di sisi lain, pembangunan yang terjadi di sekitar kampung nelayan dan munculnya hunian liar di Kawasan Muara Angke telah membuat permukiman nelayan terdesak dan juga terkesan kumuh sehingga kondisi ini tidak mendukung lingkungan kota.

\section{METODE}

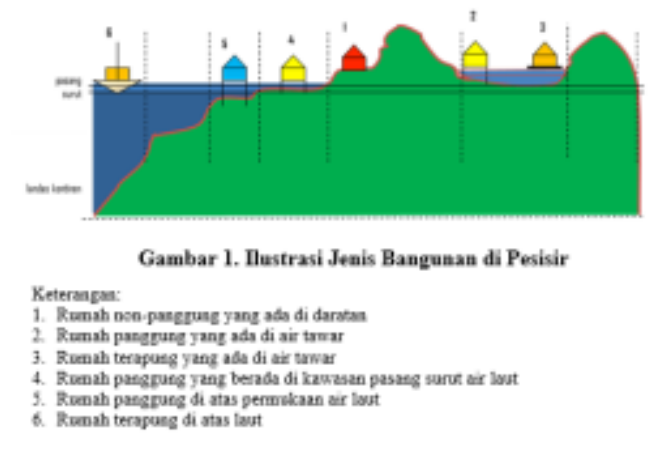

Gambar 1. Ilustrasi Jenis bangunan di Pesisir

Desain rumah di kawasan pesisir di Indonesia dapat dibedakan menjadi beberapa jenis tipe bangunan, yaitu rumah panggung dan non-panggung. Letak bangunan bisa di atas daratan, di atas air atau mengapung. Struktur utama bangunan rumah bisa menggunakan struktur kayu, struktur beton atau struktur dinding pemikul.

Peraturan Menteri Kebudayaan dan Pariwisata Nomor: Km. 67/Um.001/Mkp/2004 tentang Pedoman Umum Pengembangan Pariwisata menyatakan bahwa pembangunan pariwisata berkelanjutan adalah pembangunan yang mampu memenuhi kebutuhan wisatawan dan masyarakat di daerah tujuan saat ini dengan tetap menjaga dan meningkatkan kesempatan pemenuhan kebutuhan di masa yang akan datang. Pembangunan pariwisata berkelanjutan dicitrakan menjadi patokan dalam pengaturan sumberdaya sehingga kebutuhan ekonomi, 
sosial dan estetika tercapai, dengan tetap menjaga integritas budaya proses-proses dan keanekaragaman hayati. Selanjutnya pariwisata berkelanjutan dapat dicapai bila pertumbuhan yang selaras antara ekologi, ekonomi dan sosial serta instansi-instansi yang terkait.

Commonwealth Coastal Action Program (1997) menyatakan bahwa pengembangan pariwisata yang berkelanjutan (sustainable coastal tourism) adalah pengembangan pariwisata yang memperhatikan wilayah konservasi dan perubahan komunitas ekologi yang ditimbulkannya, meliputi perlindungan terhadap satwa liar dan menjaga kualitas kehidupan yang ada di lingkungan tersebut untuk generasi yang akan datang. Jadi pengembangan pariwisata yang berkelanjutan sangat erat kaitannya dengan keramahan lingkungan di sekitarnya.

\section{Prinsip-Prinsip Pariwisata Pesisir Berkelanjutan}

- Prinsip Keseimbangan: Pengelolaan pariwisata harus didasarkan pada komitmen pola keseimbangan antara pembangunan ekonomi, sosial budaya dan konservasi.

- Prinsip Partisipasi Masyarakat: Melibatkan masyarakat dalam pengelolaan usaha pariwisata.

- Prinsip Konservasi: Memiliki kepedulian, tanggung jawab dan komitmen terhadap pelestarian lingkungan (alam dan budaya). Pengembangan harus diselenggarakan secara bertanggung jawab dan mengikuti kaidah-kaidah ekologi serta peka dan menghormati nilainilai sosial budaya dan tradisi keagamaan masyarakat setempat.

- Prinsip Keterpaduan: Pengelolaan memperhatikan kondisi ekosistem dan disinerjikan dengan pembangunan berbagai sektor.

- Prinsip Penegakan Hukum: Pengelolaan pariwisata harus dikembangkan sesuai dengan aturan-aturan yang ada, serta dilaksanakan dengan penegakan hukum maupun peraturan yang berlaku untuk menjamin kepastian hukum dalam pengelolaan pariwisata.

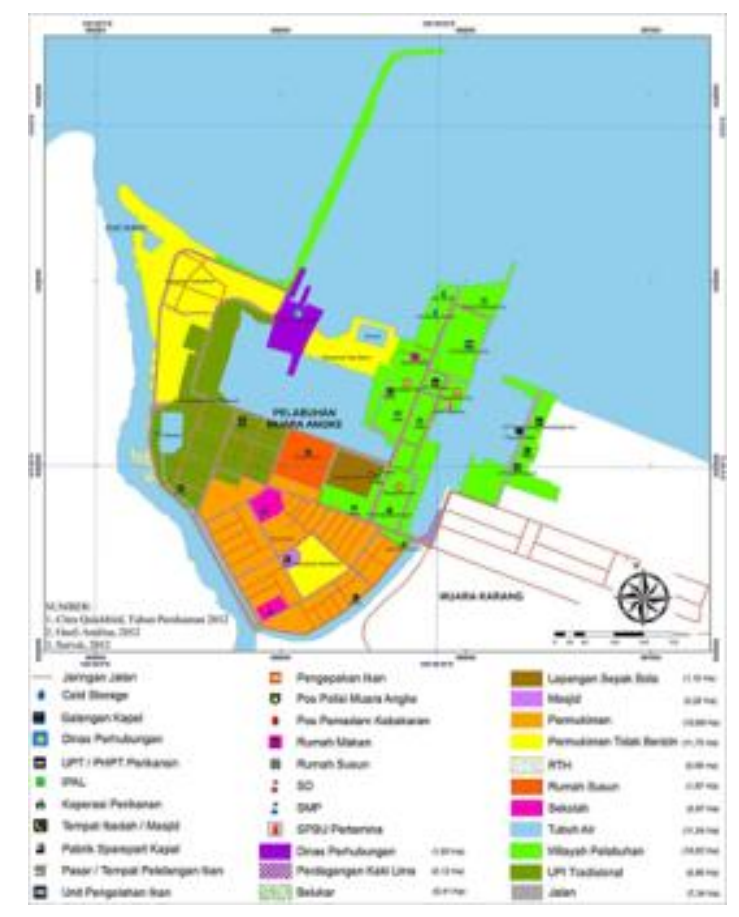

Gambar 2. Topografi Muara Angke

Kampung Nelayan Muara Angke memiliki kondisi topografi lahan dengan elevasi rata-rata 2,1 meter dari surut rendah (LWS). Kemiringan lereng pada kawasan ini tergolong datar hingga landai yang dapat dilihat pada Gambar 3.7 sehingga dapat terjadi bencana banjir. Hal ini diperparah dengan kondisi di sepanjang Kali Angke dan pantai yang telah dipenuhi oleh 
permukiman sehingga saat air pasang, daerah di sekitar Kali Angke dan pantai mengalami banjir karena lahan resapan air sudah dikonversi menjadi lahan permukiman. Keadaan saat ini sangat berbeda dengan keadaan Kampung Nelayan Muara Angke pada tahun 1960 yang sebagian besar merupakan rawa dan hutan mangrove yang Gambar 3.6 Sebaran objek/atraksi wisata yang berpeluang terkait sosial, ekonomi, dan budaya berfungsi sebagai penampung air hujan dan limpahan air, penyuplai air tanah, serta daerah resapan dataran rendah, sehingga kawasan ini terbebas dari bencana banjir. Fungsi-fungsi tersebut perlu dikembalikan dengan revegetasi hutan mangrove di tepi sungai dan pesisir, pengadaan daerah resapan air di sempadan sungai, serta sumur resapan di area permukiman.

\section{DISKUSI DAN HASIL}

Program yang diusulkan adalah Wisata Kampung Nelayan di Muara Angke yang memiliki tujuan untuk mengembangkan potensi pariwisata di daerah Muara Angke dengan mempertimbangkan aspek sosial, budaya dan ekonomi masyarakat lingkungan Muara Angke. Dari hasil analisis aspek fisik dan sosial budaya masyarakat Muara Angke, kawasan ini memiliki beberapa elemen lanskap dan budaya yang berpotensi untuk dijadikan sebagai bentuk objek dan atraksi wisata pesisir, yaitu hutan mangrove, lahan ex-tambak, Tempat Pelelangan Ikan (TPI), permukiman PHPT, pengolahan ikan asin, pengolahan otak-otak, pasar dan pusat jajanan serba ikan (pujaseri), kegiatan nelayan di laut, kegiatan nelayan di darat, dan nadran (pesta laut). Potensi masing-masing objek dan atraksi wisata dinilai berdasarkan kriteria yang telah ditetapkan dan hasil skoring yang ada pada kawasan dapat dilihat pada Tabel 1 dan Tabel 2.

Tabel 1. Nilai Skoring Objek dan Atraksi Wisata Pesisir Yang Ada

\begin{tabular}{|c|c|c|c|c|c|c|c|}
\hline Jenis Objek Mtrabsi & Keunikan | & Keutukan & Cessilan & \begin{tabular}{|c|} 
Ketericatan \\
dengan biofisi $k$
\end{tabular} & \begin{tabular}{|l|} 
Partivipavi \\
Magarakat
\end{tabular} & lumish & Kategon \\
\hline Tempat Pedidaren lkan & 2 & 4 & 4 & 2 & 4 & 16 & P. Tines \\
\hline Pinar likan & 4 & 4 & 4 & 3 & 4 & 19 & P. Titues \\
\hline Festaurant Pulasera & 3 & 3 & 3 & 4 & 4 & 17 & P. Ting: \\
\hline Kogatan néaran el last & 4 & 4 & 4 & 3 & 4 & 19 & P. Tinges \\
\hline Kayjacan nediapan di darat & 2 & 3 & 4 & 2 & 3 & 14 & P. Sediang \\
\hline Budapa Nadran atau pesta laut & 4 & 4 & 4 & 1 & 4 & 17 & P.Tinger \\
\hline Permainan anak tradisions & 3 & 3 & 3 & 1 & 2 & 12 & p, Sedang \\
\hline Hutan Matgrovet & 3 & 2 & 1 & 2 & 2 & 10 & P. Sedang \\
\hline Edukas Mongrove & 3 & 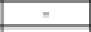 & 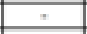 & 3 & 2 & 8 & P. Aendath \\
\hline Penpamstan burung & 3 & - & 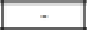 & 2 & 3 & 5 & P. Alendigh \\
\hline Rewa & 2 & 3 & 1 & 3 & 2 & 11 & P. Sedang \\
\hline Kegasan pensmbjkan & 2 & 3 & 2 & 3 & 2 & 12 & P. Sedang \\
\hline
\end{tabular}

Sumber: olahan pribadi

Tabel 2. Nilai Skoring Objek dan Atraksi Wisata Pesisir Tambahan

Nilai hasil skoring masing-masing objek dan atraksi wisata pesisir tambahan di Kampung Nelayan Muara Angke

\begin{tabular}{|l|c|c|c|c|c|c|c|}
\hline \multicolumn{1}{|c|}{ Jenis Objek Atraksl } & Keunikan & Keutuhan & Keaslian & $\begin{array}{c}\text { Keterkaitan } \\
\text { dengan biofisik }\end{array}$ & $\begin{array}{c}\text { Partisi pasi } \\
\text { Masyarakat }\end{array}$ & Jumlah & Kategori \\
\hline Pembuatan kerajinan tangan & 4 & - & - & 2 & 4 & 10 & P. Sedang \\
\hline Pusat Souvenir & 4 & - & - & 2 & 4 & 10 & P. Sedang \\
\hline
\end{tabular}

Keterangan: Potensi tinggi $(\geq 15-20)$, potensi sedang $(210-<15)$, potensi rendah $(\geq 5-<10)$

Sumber: olahan pribadi

Keseluruhan objek dan atraksi wisata dapat dijadikan sebagai zona wisata utama. Namun, objek dan atraksi wisata yang memiliki potensi sedang perlu dilakukan peningkatan kualitas dan kuantitas, yaitu revegetasi mangrove dan budidaya tambak. Selain itu, hampir seluruh kondisi biofisik dimana letak objek dan atraksi tersebut kurang mendukung sehingga diperlukan perbaikan lebih lanjut guna menunjang keberlangsungan wisata. Berdasarkan hasil analisis maka didapatkan peta kesesuaian lahan wisata dan peta kehidupan masyarakat Muara Angke. Area yang didalamnya terdapat aktivitas khas masyarakat Muara Angke dengan skala kecil tetapi tidak terlihat aktivitasnya yang nyata tidak termasuk ke dalam zona wisata. Namun, 
mengingat pokok permasalahannya adalah permasalahan di segi ekonomi, maka harus mencoba memperbaiki aspek-aspek wisata yang memihak akan membangun proyek yang melibatkan masyarakat sekitar. Dengan menggunakan konsep konektivitas, diharapkan akan dapat menyambungkan 2 titik poin wisata. PHPT (Penghasil hasil perikanan tradisional) dengan Pasar ikan Muara Angke. Supaya dapat memperbaiki dan membuat kawasan lebih hidup. Konsep perencanaan yang dikembangkan pada Kawasan Muara Angke, Jakarta Utara adalah wisata pesisir yang mencirikan Kawasan Muara Angke, yaitu kegiatan perikanan dan pengolahan ikan dengan mengkombinasikan aspek fisik dan sosial budaya untuk meningkatkan kesejahteraan masyarakat lokal. Penerapan konsep perancangan "Emerges" untuk mengembalikan kesejahteraan dan kejayaan Muara Angke. Diharapkan juga proyek pengembangan ini akan menjadi icon wilayah Muara Angke.

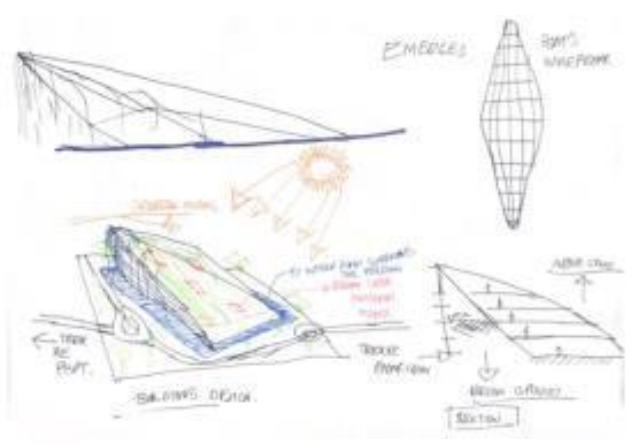

Gambar 3. Ilustrasi Konsep Emerges

Gubahan Massa diambil dari bentuk kapal. Yang menganalogikan kawasan Muara Angke adalah suatu kapal yang megah, tapi telah "tenggelam" karena telah ditinggalkan pembangunannya oleh sekitar. Oleh karena itu, untuk mengembalikan kejayaan kawasan itu. Proyek bangunan diharapkan akan menjadi icon kawasan.
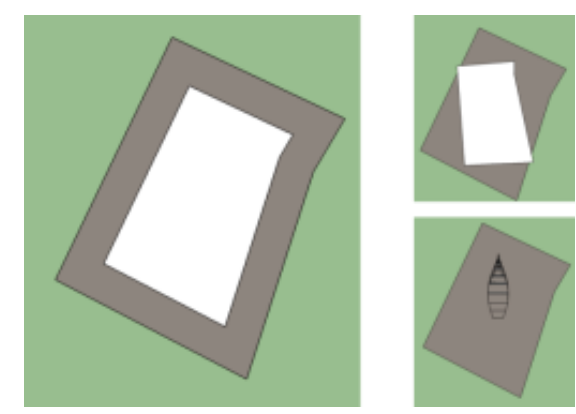

Gambar 4. Proses Gubahan Massa 1

Bangunan di putar 30 derajat ke arah Barat, karena seperti halnya kapal massa lalu yang menggunakan orientasi sudut layar untuk memaksimalkan laju kapal.
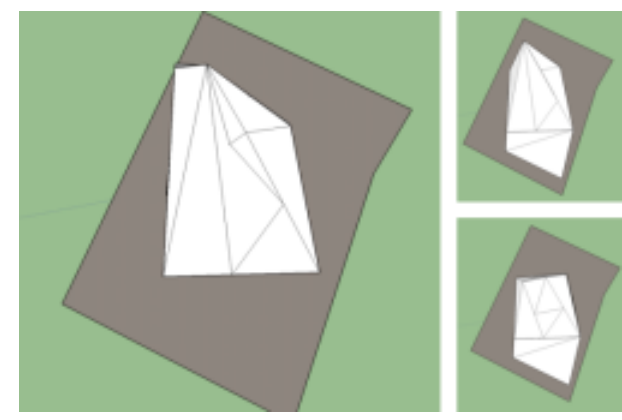

Gambar 5. Proses Gubahan Massa 2 
Massing bangunan dibuat menyerupai bentuk kapal yang tenggelam, dengan khas "moncong" kapal yang ada diujung depan.

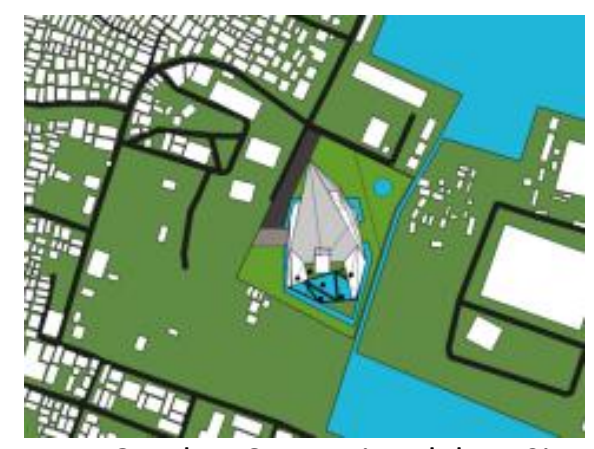

Gambar 6. Massing dalam Site

Tabel 3. Program Ruang

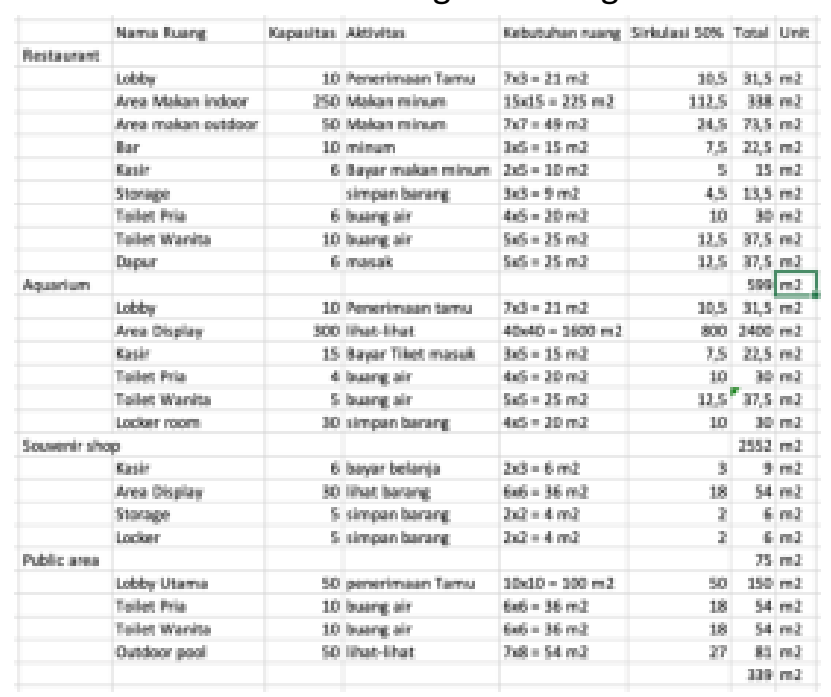

Sumber: olahan pribadi

Program ruang yang akan dibuat di dalam perancangan ini berfokus ke dalam perbaikan ekonomi. Karena banyaknya masyarakat nelayan yang terancam tidak dapat berlayar, program ruang yang ditawarkan diharapkan dapat membantu mereka, yaitu:

\section{Aquarium.}

Aquarium ini akan membantu masyarakat sekitar untuk menjadi objek wisata yang akan menarik wisatawan, dan juga akan menjadi edukasi ke masyarakat sekitar. Tentang banyaknya biota laut Indonesia. Karena nelayan memiliki banyak pengetahuan tentang biota laut, diharapkan pengembangan ini akan menjadi bantuan ke masyarakat supaya dapat maju dan bekerja sebagai tim edukasi ke masyarakat tentang biota biota laut.

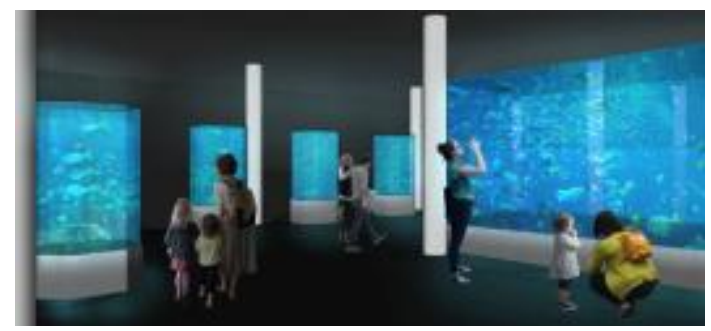

Gambar 7. Ilustrasi design Aquarium 


\section{Restaurant.}

Restaurant disini akan dibuat, karena banyak sekali pujasera disana yang terancam tutup karena tidak laku. Karena kondisi lingkungan yang tidak bersih, maka masyarakat memutuskan untuk tidak menikmati santapan khas area tersebut. Bumbu masakan yang sudah turun temurun diturunkan oleh masyarakat.

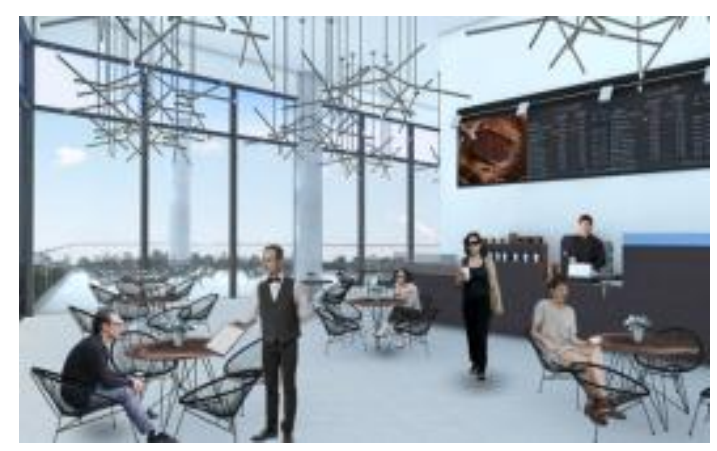

Gambar 8. Ilustrasi design Restaurant

\section{Souvenir shop}

PHPT di Muara Angke menghasilkan banyak kerajinan tangan dan makanan ringan khas Muara Angke, namun dikarenakan tidak ada wadah yang membantu penjualan, kerajinan hasil khas Muara Angke menjadi kurang laku.

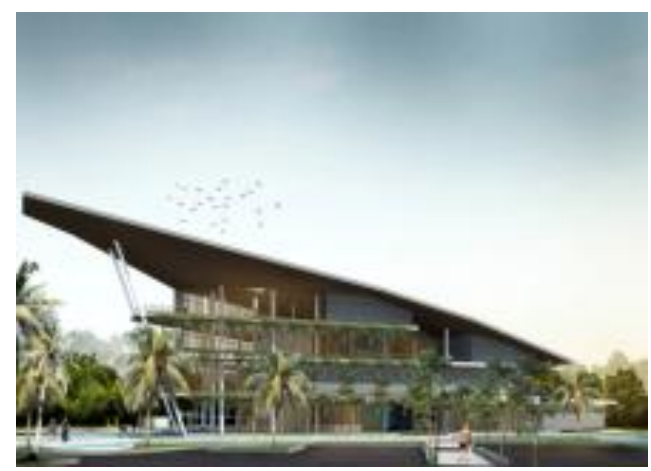

Gambar 9. Design Bangunan

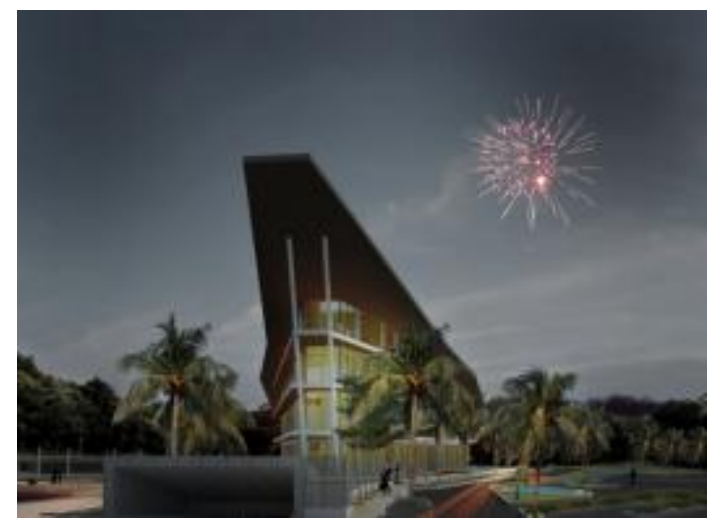

Gambar 10. Design Bangunan

\section{KESIMPULAN DAN SARAN}

Untuk mengembalikan citra kawasan Muara Angke supaya dapat menjadi kawasan yang baik. Diperlukan ikon kawasan yang dapat memperbaiki kawasan dan mengundang pengunjung ke dalam kawasan Muara Angke. Ikon kawasan ini diharapkan akan memperbaiki 
isu:

- Ekonomi. Untuk memperbaiki pekerjaan nelayan yang mulai hilang dan mulai ditinggalkan oleh nelayan. Oleh karena itu, menciptakan program ruang yang akan membantu menciptakan lapangan pekerjaan akan membuat nelayan menjadi memiliki pekerjaan yang masih menjadi keterampilannya.

- Pendidikan. Untuk membantu masyarakat untuk lebih mengenal biota laut, dan mempelajarinya. Dan meningkatkan pengetahuan masyarakat akan pentingnya kelangsungan hidup biota laut dan mengapa kita harus menjaganya.

- Rekreasi. merupakan fungsi untuk beraktivitas di Muara Angke dan menikmati keindahan dan kegiatan Nelayan di kota Metropolis Jakarta.

Dampak yang akan diterima kota Jakarta sebagai kota Metropolis diharapkan dapat menjadi ikon wisata baru, dan mengembalikan citra baik dari kawasan Muara Angke. Selain itu, Kota Jakarta sebagai kota Metropolitan, memiliki tempat rekreasi kota yang memperkenalkan khas hasil kerajinan tangan, makanan budaya asli Betawi.

\section{REFERENSI}

Breen, Ann; Rigby, Dick. (1994). Waterfronts - Cities Reclaim Their Edge. Amerika: Kim Hupp Lee.

Baud-bovy, Manuel \& Fred Lawson. (1997). Tourism and Recreation Development : A Handbook of Physical Planning. Great Britain : The Architectural Press Ltd.

De Chiara, Joseph; J Crosbie, Michael. (2001).Time Saver Standards for Building Types.Singapore :McGraw Hill Book Companies Inc. Echols, J.M. dan Shadily, H. 2005. Kamus Inggris Indonesia : An English - Indonesian Dictionary. PT Gramedia, Jakarta.

Lee, Uje. (2010). Waterfront; Resewing the City Plaza and Square in Europe. Korea: Art Data. Specht, Jan. (2014). Architectural Tourism. Belanda : Springler Gabler.

Torre, L. A. (1989). Waterfront development. New York: Van Nostrand Reinhold

Wren, Douglas M. (1983). Urban Waterfront Development. Urban Land Institue: Washington D.C

https://www.healthline.com/nutrition/16-ways-relieve-stress-anxiety\#section1 (Diakses tanggal 13 Juli 2018 pukul 3:11)

https://www.medcom.id/rona/kesehatan/ybDMMMjk-Jakarta-dinobatkan-salah-satu-kotadengan-tingkat-stres-tinggi-psikolog-itu-lumrah (Diakses tanggal 29 Juli 2018 pukul 19:00) https://databoks.katadata.co.id/datapublish/2017/01/27/penduduk-dki-Jakarta-didominasiumur-25-34-tahun (Diakses tanggal 16 Juli 2018 pukul 3:14) https://www.nationalwellness.org/? (Diakses tanggal 29 Juli 2018 pukul 7:04) http://tataruang.atr-bpn.go.id/Bulletin/index.asp?mod=_fullart\&idart=218 (Diakses tanggal 7 September 2018 pukul 2:54) 